\title{
Preparation of Catalyst for Hydrogen Production Reaction of Sodium Borohydride and Its Effectiveness
}

\author{
Jyun-Lin Lai, ${ }^{1}$ Win-Jet Luo, ${ }^{1}$ and Yean-Der Kuan ${ }^{2 *}$ \\ ${ }^{1}$ Graduate Institute of Precision Manufacturing, National Chin-Yi University of Technology, \\ No. 57, Sec. 2, Zhongshan Rd., Taiping Dist., Taichung City 41170, Taiwan \\ ${ }^{2}$ Department of Chemical and Materials Engineering, National Chin-Yi University of Technology, \\ No. 57, Sec. 2, Zhongshan Rd., Taiping Dist., Taichung City 41170, Taiwan
}

(Received May 2, 2020; accepted October 25, 2020)

Keywords: $\mathrm{NaBH}_{4}$ catalyst, $\mathrm{Co}$, hydrogen production, gas sensor

The fundamental purpose of this study is to produce a catalyst for catalyzing the hydrogen production reaction of sodium borohydride $\left(\mathrm{NaBH}_{4}\right)$. The catalyst for catalyzing this reaction includes a catalyst carrier and a metal catalyst. We use three catalyst bed temperatures with the same $\gamma-\mathrm{Al}_{2} \mathrm{O}_{3}$ carrier and gas sensor, with different chelate concentration processes to make the catalyst. The metal catalyst selected is Co. The effects of the catalyst produced by different catalyst carrier processes on the hydrogen production efficiency and total hydrogen yield of $\mathrm{NaBH}_{4}$ solution are discussed. The experiment shows that when the catalyst soaked in $30 \mathrm{wt} \%$ $\mathrm{Co} / \gamma-\mathrm{Al}_{2} \mathrm{O}_{3}$ is used at $70{ }^{\circ} \mathrm{C}$, the rate and hydrogen production efficiency are $5300 \mathrm{ml} / \mathrm{min} \mathrm{g}$ cat and $82.92 \%$, respectively. The catalyst has a vigorous hydrolytic hydrogen production reaction with $\mathrm{NaBH}_{4}$. This catalyst can be combined with a fuel cell system for hydrolytic hydrogen production to generate power in the future, enabling the portability and efficiency of stored hydrogen to be enhanced effectively.

\section{Introduction}

In recent years, with the development of the hydrogen-oxygen fuel cell, many scholars have studied hydrogen storage. The present hydrogen storage techniques are divided into six main classes, which are compression hydrogen storage, liquefaction hydrogen storage, carbon nanotubes, metal hydrogen storage, recombination hydrogen storage, and chemical hydrogen storage. $^{(1)}$ In comparison with other hydrogen storage techniques, chemical hydrogen storage has high volume energy density and high weight energy density, the hydrogen production rate can be adjusted only by using the catalyst, and the conversion efficiency is high. ${ }^{(2-4)}$ Sodium borohydride $\left(\mathrm{NaBH}_{4}\right)$ has been paid close attention as a material for chemical hydrogen storage owing to its high hydrogen content (10.8 wt\%), its stability in an alkaline liquid and nonflammability, and its controllable, environmentally benign, and renewable hydrolysis reaction. ${ }^{(5,6)}$ With an appropriate catalyst, $\mathrm{NaBH}_{4}$ is hydrolyzed into hydrogen and $\mathrm{NaBO}_{2}$, where the equation is expressed as ${ }^{(7)}$

*Corresponding author: e-mail: ydkuan@ncut.edu.tw

https://doi.org/10.18494/SAM.2020.3098 


$$
\mathrm{NaBH}_{4}+2 \mathrm{H}_{2} \mathrm{O} \stackrel{\text { catalyst }}{\rightarrow} 4 \mathrm{H}_{2}+\mathrm{NaBO}_{2}+217 \mathrm{~kJ}
$$

The hydrogen production rate of the hydrolysis reaction of $\mathrm{NaBH}_{4}$ is related to the metal catalyst applied. The common metal catalysts are $\mathrm{Fe}, \mathrm{Co}, \mathrm{Ni}, \mathrm{Ru}, \mathrm{Rh}$, and Pd chlorides, but an aqueous solution of partial metal chlorides reduces the hydrolytic hydrogen production reaction rate. $^{(8)} \mathrm{Kreevoy}^{(9)}$ found that $\mathrm{pH}$ and temperature had a significant effect on the autohydrolytic hydrogen production rate of $\mathrm{NaBH}_{4}$ in water. The hydrolytic hydrogen production rate of $\mathrm{NaBH}_{4}$ at ambient temperature is very low for alkaline byproducts and can be increased effectively by changing the $\mathrm{pH}$ and temperature. Kojima et al. ${ }^{(10)}$ made a $\mathrm{Pt} / \mathrm{LiCoO}_{2}$ catalyst of multiple metal oxide carriers. Although the metal catalyst was not a metal chloride compound, the carrier supported the metal catalyst. However, these metal catalysts are expensive and rare metals or have little catalytic effect and low economic efficiency, making them inapplicable to mass production in the future. Ye et al. ${ }^{(11)}$ found that an $\alpha-\mathrm{Al}_{2} \mathrm{O}_{3}$-loaded Co catalyst was very effective owing to its special structure. They used a $\mathrm{Co} / \beta-\alpha-\mathrm{Al}_{2} \mathrm{O}_{3}$ catalyst with $9 \%$ catalyst by weight at an ambient temperature of $303 \mathrm{~K}$, and a rate of $220 \mathrm{~mL} / \mathrm{min}^{-1} \mathrm{~g}^{-1}$ catalyst and about $100 \%$ hydrogen production rate were obtained at $303 \mathrm{~K}$. Ke et al. ${ }^{(12)}$ found that the rate of the hydrolytic hydrogen production reaction catalyzed by a Co-B catalyst modified by Mo was $4200 \mathrm{ml} / \mathrm{min} \mathrm{H}_{2}$ and indicated that the hydrolytic hydrogen production reaction rate depended on the amount of $\mathrm{NaBH}_{4}$ adsorbed on the catalyst surface. In addition, the interaction between $\mathrm{NaBH}_{4}$ and water doubles the hydrogen yield; the reducing reaction of water protons increases the hydrogen yield. ${ }^{(13)}$

In this paper, we design a low-cost catalyst for catalyzing the hydrolytic hydrogen production reaction of $\mathrm{NaBH}_{4}$, which uses a catalyst carrier to load a metal catalyst. The effects of the produced catalyst on the hydrogen production efficiency and total hydrogen yield of the hydrolytic hydrogen production reaction of $\mathrm{NaBH}_{4}$ are discussed.

\section{Materials and Methods}

\subsection{Design of catalyst production}

To design a catalyst for catalyzing the hydrolytic hydrogen production reaction of $\mathrm{NaBH}_{4}$, we use the process designs and production methods proposed by previous scholars as a reference frame. Kim et al. ${ }^{(14)}$ used $\gamma-\mathrm{Al}_{2} \mathrm{O}_{3}$ as a catalyst carrier, which was soaked in $\mathrm{CoCl}_{2}$ solution to load the metal catalyst $\mathrm{Co}$, baked at $350{ }^{\circ} \mathrm{C}$ for $3 \mathrm{~h}$, and then reduced. The produced catalyst $\mathrm{Co} / \mathrm{Al}_{2} \mathrm{O}_{3}$ had a maximum hydrogen production efficiency of $1071 \mathrm{ml} / \mathrm{min}$ when the $\mathrm{NaBH}_{4}$ solution input rate was $3 \mathrm{ml} / \mathrm{min}$. Hsueh et al. ${ }^{(15)}$ used AMBERLITE IR-120 PLUS ion-exchange resin (sodium form) as a catalyst carrier, which was soaked in $\mathrm{RuCl}_{3}$ solution to load the metal catalyst $\mathrm{Ru}$ and baked at $80{ }^{\circ} \mathrm{C}$. The produced catalyst $\mathrm{Ru} / \mathrm{IR}-120$ had a maximum hydrogen production efficiency of $132 \mathrm{ml} / \mathrm{min}$ g cat for $\mathrm{NaBH}_{4}$ solution at $25{ }^{\circ} \mathrm{C}$ and a concentration of $5 \mathrm{wt} \% \mathrm{NaBH}_{4}+1 \mathrm{wt} \% \mathrm{NaOH}$. The low-cost and convenient catalyst carrier $\gamma-\mathrm{Al}_{2} \mathrm{O}_{3}$ was used in the references. As a metal catalyst, Kim et al. ${ }^{(14)}$ used the non-noble metal 
chloride compound $\mathrm{CoCl}_{2}$. In this study, we design a catalyst for catalyzing the hydrolytic hydrogen production reaction of $\mathrm{NaBH}_{4}$ that has the aforementioned catalyst production characteristics. $\gamma-\mathrm{Al}_{2} \mathrm{O}_{3}$ is used as a catalyst carrier in this study, with the non-noble metal chloride compound $\mathrm{CoCl}_{2}$. The metal catalyst $\mathrm{Co}$ is loaded on the $\gamma-\mathrm{Al}_{2} \mathrm{O}_{3}$ catalyst carrier, and different baking temperatures are used for different catalyst carriers.

\subsection{Catalyst preparation process}

The catalyst carrier used in this study is $\gamma-\mathrm{Al}_{2} \mathrm{O}_{3}$, as shown in Fig. 1. The production of the catalyst for catalyzing the hydrolytic hydrogen production reaction of $\mathrm{NaBH}_{4}$ depends on the characteristics of the catalyst carrier.

\subsubsection{Production of $\mathrm{Co}^{2+} / \mathrm{Al}_{2} \mathrm{O}_{3}$ catalyst}

In the production of the $\mathrm{Co}^{2+} / \mathrm{Al}_{2} \mathrm{O}_{3}$ catalyst, $\gamma-\mathrm{Al}_{2} \mathrm{O}_{3}$ is cleaned with $\mathrm{DI}$ water and baked in a vacuum oven at $120{ }^{\circ} \mathrm{C}$ for $4 \mathrm{~h}$ to remove moisture. The oven-dried $\gamma-\mathrm{Al}_{2} \mathrm{O}_{3}$ is soaked in 10,20 , or $30 \mathrm{wt} \% \mathrm{CoCl}_{2}$ solution for $24 \mathrm{~h}$, so that the $\mathrm{Co}$ in $\mathrm{CoCl}_{2}$ solution fully adheres to $\gamma-\mathrm{Al}_{2} \mathrm{O}_{3}$, and then the redundant $\mathrm{CoCl}_{2}$ solution is filtered, as shown in Fig. 2. Finally, the $\gamma-\mathrm{Al}_{2} \mathrm{O}_{3}$ from the filtered $\mathrm{CoCl}_{2}$ solution is heated in vacuum at $120{ }^{\circ} \mathrm{C}$ for $6 \mathrm{~h}$ to obtain the catalyst $\mathrm{Co}^{2+} / \mathrm{Al}_{2} \mathrm{O}_{3}$, as shown in Fig. 3 .

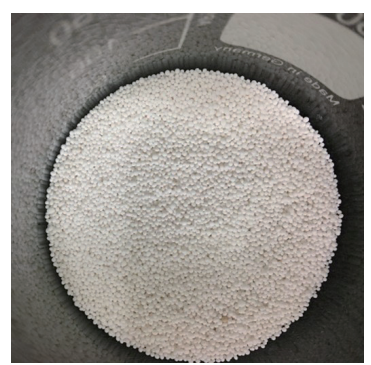

Fig. 1. (Color online) Catalyst carrier $\mathrm{Al}_{2} \mathrm{O}_{3}$.

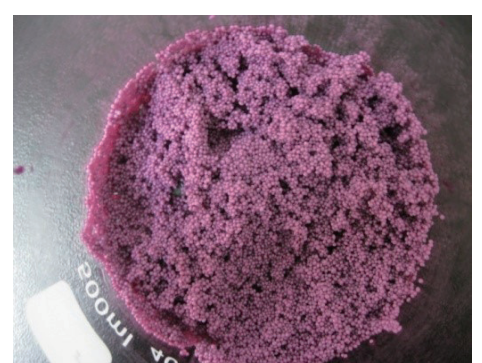

Fig. 2. (Color online) $\gamma-\mathrm{Al}_{2} \mathrm{O}_{3}$ from filtered $\mathrm{CoCl}_{2}$ solution.

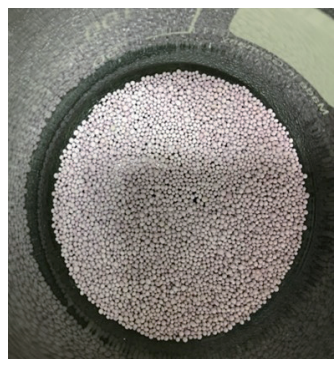

(a)

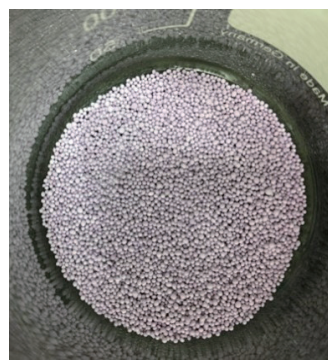

(b)

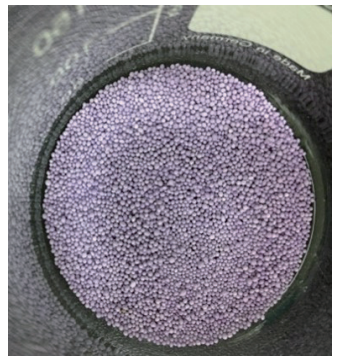

(c)

Fig. 3. (Color online) $\gamma-\mathrm{Al}_{2} \mathrm{O}_{3}$ from $\mathrm{CoCl}_{2}$ solutions at different concentrations. (a) $10 \mathrm{wt} \%$, (b) $20 \mathrm{wt} \%$, and (c) $30 \mathrm{wt} \%$. 


\subsection{Experimental setup for evaluating hydrogen production efficiency}

The experimental setup for evaluating hydrogen production efficiency is shown in Fig. 4. The $\mathrm{NaBH}_{4}$ solution with a concentration of $10 \mathrm{wt} \% \mathrm{NaBH}_{4}+1 \mathrm{wt} \% \mathrm{NaOH}$ is injected into the hydrogen production container, and then the catalyst is placed in it to generate hydrogen. The hydrogen flows through the gas-drying tower, and the hydrogen mass sensor reads the hydrogen production efficiency and total hydrogen yield of various catalysts. Finally, the flow recording program records the hydrogen production efficiency and total hydrogen yield. When the reading of the hydrogen mass sensor is zero, the experiment is terminated and recording is stopped.

\subsubsection{Hydrogen production container}

In the initial experiment, as general conical flasks cannot be used to control the catalyst bed temperature, a special two-layer hydrogen production reaction container is made. The inner layer is the hydrogen production reaction chamber and the outer layer is the insulating layer, the water temperature in which controls the catalyst reaction temperature. The catalyst bed temperature can be controlled by this design during the experiment.

\subsubsection{Gas filter flask}

In addition to pure hydrogen, the hydrogen generated in the hydrogen production container contains fine water globules and water vapor; thus, an instrument for removing the moisture is required. We use a gas filter flask to remove the moisture in the gas. A silica-gel dryer is placed in the gas filter flask to adsorb the moisture in the mixed gas of hydrogen and water vapor generated in the hydrogen production container, so as to purify the hydrogen. As a result, the hydrogen mass sensor only reads the mass flow of hydrogen.

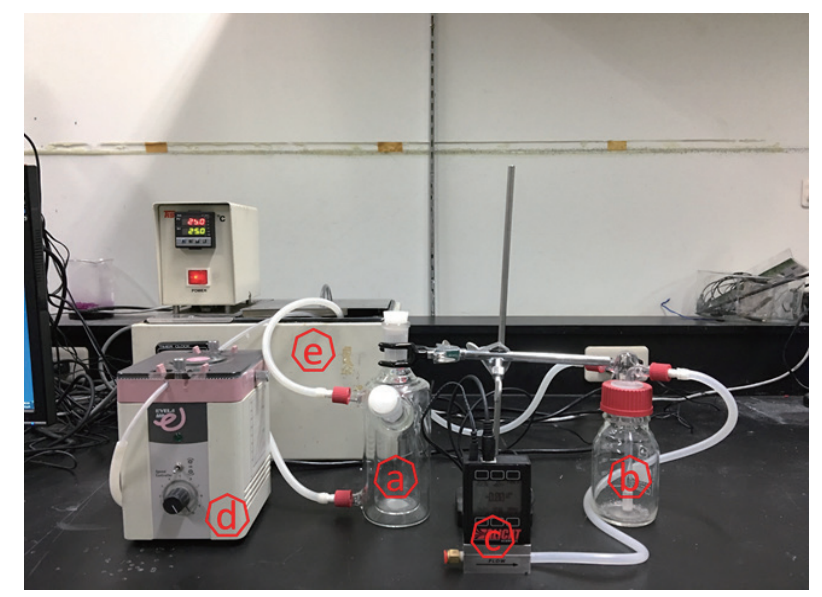

Fig. 4. (Color online) Experimental setup for evaluating hydrogen production efficiency: (a) hydrogen production container, (b) gas filter flask, (c) hydrogen mass sensor, (d) catalyst bed flow pump, and (e) catalyst bed constant temperature water tank. 


\subsubsection{Hydrogen mass flowmeter and mass flow recording program}

The flowmeter used in this study can read and display the hydrogen mass flow through the hydrogen mass sensor, and can obtain the cumulative total hydrogen volume through the hydrogen mass sensor. The hydrogen mass flow and cumulative total hydrogen volume are recorded once per second by setting the mass flow recording program.

\section{Experimental Results}

\subsection{Test for hydrogen production efficiency of $\mathrm{Co}^{2+} / \mathrm{Al}_{2} \mathrm{O}_{3}$ catalyst}

Table 1 shows the $\mathrm{Co} / \mathrm{Al}_{2} \mathrm{O}_{3}$ catalyst manufacturing parameters: the three chelate concentrations are 10,20, and 30\%, the three chelate soaking times are 24,36 , and $72 \mathrm{~h}$, the bake-out period is $6 \mathrm{~h}$, the baking temperature is $120^{\circ} \mathrm{C}$, the drying time after the alumina is cleaned is $4 \mathrm{~h}$, and the hydrogen production container is filled with $5.56 \mathrm{~g}$ of $10 \mathrm{wt} \% \mathrm{NaBH}_{4}+1$ $\mathrm{wt} \% \mathrm{NaOH}$. The experimental measurement data are shown in Fig. 5. The hydrogen production rates of catalysts at $25{ }^{\circ} \mathrm{C}$ are compared. The experimental measurement data show that the 30 wt $\%$ catalyst has the highest hydrogen production rate and the $10 \mathrm{wt} \%$ catalyst has the lowest efficiency. Table 2 shows the experimental hydrogen production rates. It is observed that the 30 $\mathrm{wt} \% \mathrm{Co} / \mathrm{Al}_{2} \mathrm{O}_{3}+2 \mathrm{wt} \% \mathrm{NaOH}$ has the highest efficiency. The experimental measurement data in Fig. 6 show the hydrogen production rates of the catalysts at $25{ }^{\circ} \mathrm{C}$. These data also show

Table 1

$\mathrm{Co} / \mathrm{Al}_{2} \mathrm{O}_{3}$ catalyst condition parameters.

\begin{tabular}{lccccc}
\hline $\begin{array}{l}\text { Experimental } \\
\text { conditions }\end{array}$ & $\begin{array}{c}\text { Chelate } \mathrm{CoCl}_{2} \\
\text { concentration }(\mathrm{wt} \%)\end{array}$ & $\begin{array}{c}\text { Chelate } \mathrm{CoCl}_{2} \\
\text { soaking time }(\mathrm{h})\end{array}$ & Drying time $(\mathrm{h})$ & $\begin{array}{c}\text { Baking } \\
\text { temperature }\left({ }^{\circ} \mathrm{C}\right)\end{array}$ & $\begin{array}{c}\mathrm{Al}_{2} \mathrm{O}_{3} \text { oven-drying } \\
\text { dewatering time }(\mathrm{h})\end{array}$ \\
\hline 1 & 10 & 24 & 6 & 120 & 4 \\
2 & 20 & 48 & 6 & 120 & 4 \\
3 & 30 & 72 & 6 & 120 & 4 \\
\hline
\end{tabular}

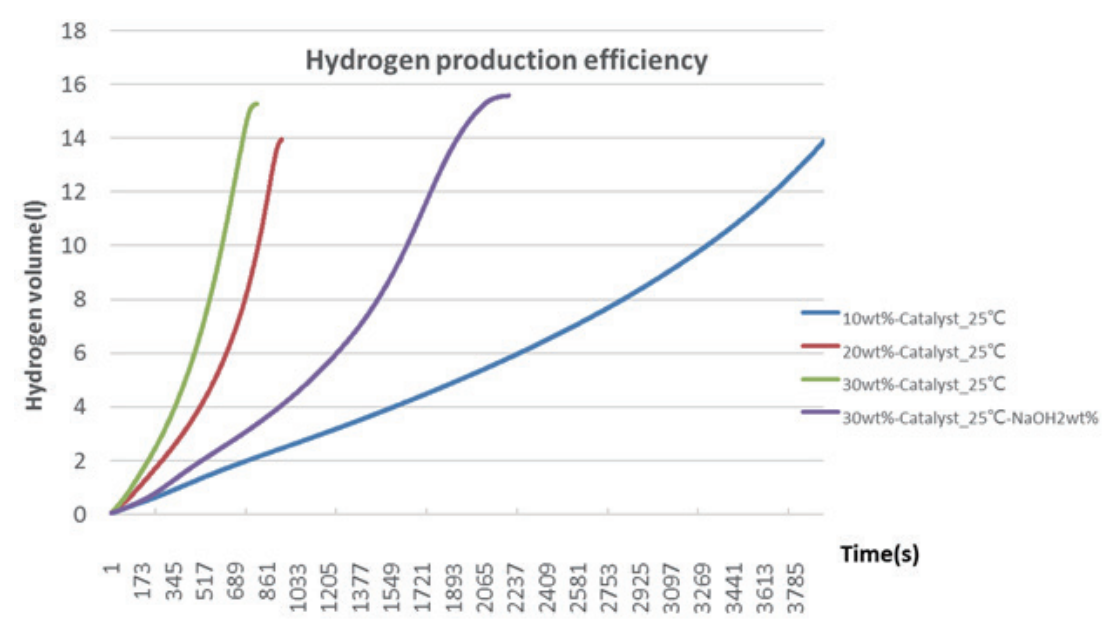

Fig. 5. (Color online) Hydrogen production rates at $\mathrm{Co} / \mathrm{Al}_{2} \mathrm{O}_{3}$ catalyst bed temperature of $25^{\circ} \mathrm{C}$. 
Table 2

Hydrogen production rates as percentages when $\mathrm{Co} / \mathrm{Al}_{2} \mathrm{O}_{3}$ catalyst bed temperature is $25^{\circ} \mathrm{C}$.

\begin{tabular}{lccc}
\hline $\begin{array}{l}\text { Experimental } \\
\text { conditions }\end{array}$ & Total hydrogen yield (L) & $\begin{array}{c}\text { Theoretical hydrogen } \\
\text { production rate }(\mathrm{L})\end{array}$ & $\begin{array}{c}\text { Hydrogen production rate } \\
(\%)\end{array}$ \\
\hline $10 \mathrm{wt} \%+\mathrm{NaOH} \_1 \mathrm{wt} \%$ & 13.898 & 15.605 & 89.06 \\
$20 \mathrm{wt} \%+\mathrm{NaOH} \_1 \mathrm{wt} \%$ & 13.952 & 15.605 & 89.4 \\
$30 \mathrm{wt} \%+\mathrm{NaOH} \_1 \mathrm{wt} \%$ & 15.281 & 15.605 & 97.92 \\
$30 \mathrm{wt} \%+\mathrm{NaOH} 2 \mathrm{wt} \%$ & 15.585 & 15.605 & 99.87 \\
\hline
\end{tabular}

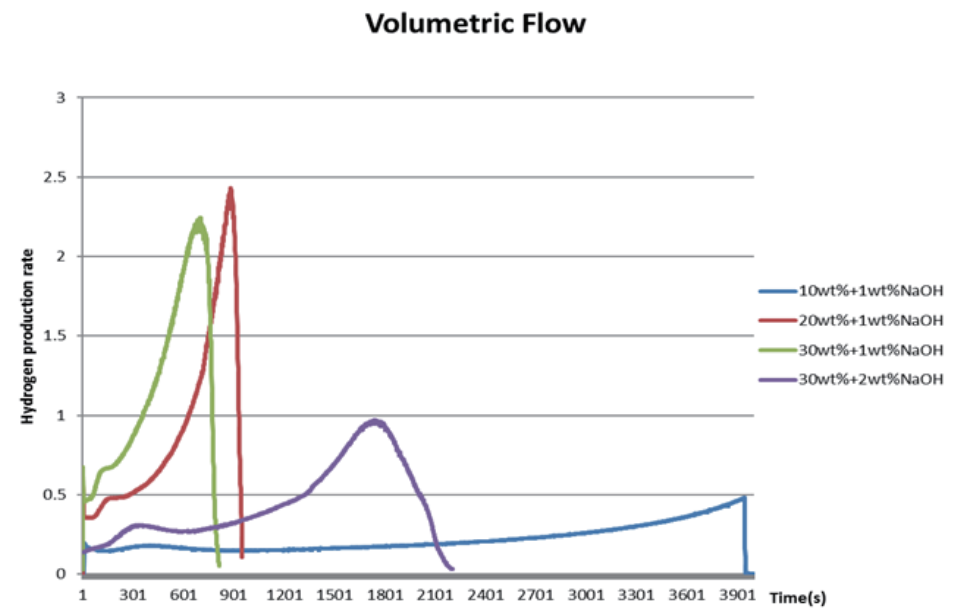

Fig. 6. (Color online) Hydrogen production rates at $\mathrm{Co} / \mathrm{Al}_{2} \mathrm{O}_{3}$ catalyst bed temperature of $25^{\circ} \mathrm{C}$.

that the $20 \mathrm{wt} \%$ catalyst has the highest hydrogen production rate with a maximum hydrogen production efficiency of $2434 \mathrm{ml} / \mathrm{min} \mathrm{g}$ cat, the total hydrogen yield is $14.01 \mathrm{~L}$, and the $10 \mathrm{wt} \%$ catalyst has the lowest hydrogen production rate.

According to the maximum hydrogen production efficiency of three chelate concentrations, the maximum hydrogen production efficiency and the hydrogen production rate increase significantly when the chelate concentration is increased. When the $\mathrm{NaOH}$ concentration is increased from 1 to $2 \mathrm{wt} \%$, the hydrogen production rate is significantly reduced, but the hydrogen production efficiency is increased to $99.87 \%$.

\subsection{Test for hydrogen production efficiency of $\mathrm{Co}^{2+} / \mathrm{Al}_{2} \mathrm{O}_{3}$ catalyst on $65^{\circ} \mathrm{C}$ catalyst bed}

The hydrogen production container is filled with $1.5 \mathrm{~g}$ of $10 \mathrm{wt} \% \mathrm{NaBH}_{4}+1 \mathrm{wt} \% \mathrm{NaOH}$. The experimental measurement data in Fig. 7 show the catalyst hydrogen production rates when the catalyst bed temperature is $65^{\circ} \mathrm{C}$. These data also show that the $20 \mathrm{wt} \%$ catalyst has the highest hydrogen production rate and that the $30 \mathrm{wt} \%$ catalyst has the lowest hydrogen production rate. Table 3 shows a comparison of hydrogen production rates. The maximum hydrogen production rate is $99.13 \%$ when the concentration is $20 \mathrm{wt} \%$. The experimental measurement data in Fig. 8 show the catalyst hydrogen production rates at $65{ }^{\circ} \mathrm{C}$. These data also show that the 30 $\mathrm{wt} \%$ catalyst has the highest hydrogen production rate with a maximum hydrogen production efficiency of $5300 \mathrm{ml} / \mathrm{min} \mathrm{g}$ cat and that the $10 \mathrm{wt} \%$ catalyst has the lowest hydrogen production rate. 


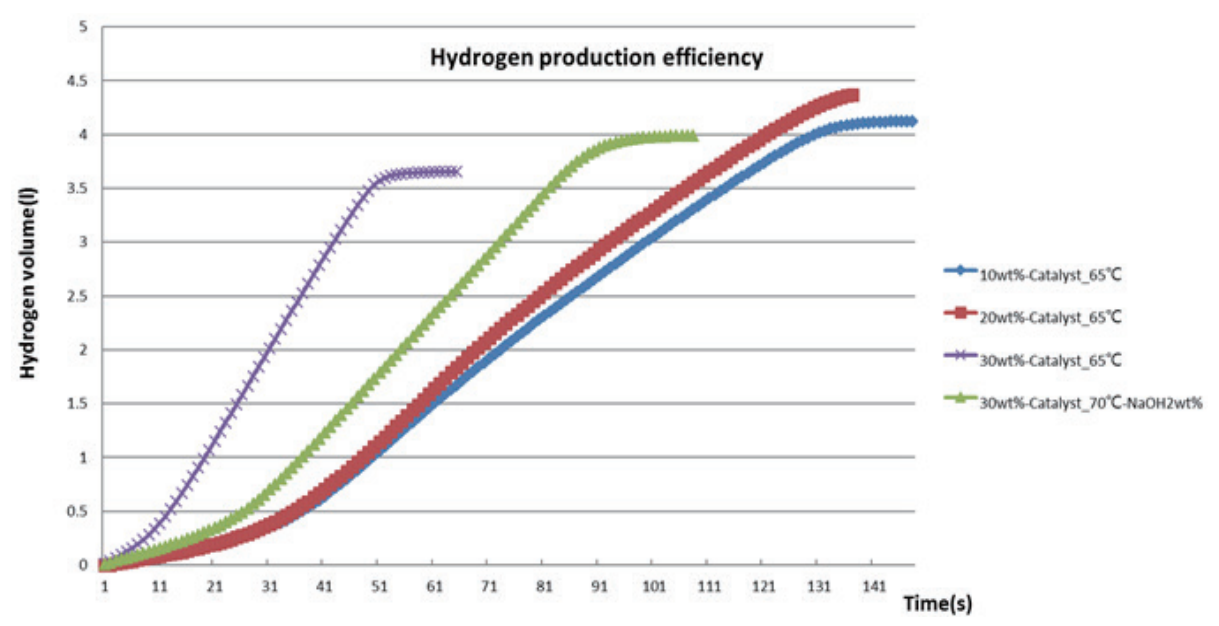

Fig. 7. (Color online) Hydrogen production rates at $\mathrm{Co} / \mathrm{Al}_{2} \mathrm{O}_{3}$ catalyst bed temperatures of 65 and $70{ }^{\circ} \mathrm{C}$.

Table 3

Hydrogen production rates as percentages at $\mathrm{Co} / \mathrm{Al}_{2} \mathrm{O}_{3}$ catalyst bed temperatures of 65 and $70{ }^{\circ} \mathrm{C}$.

\begin{tabular}{lccc}
\hline $\begin{array}{l}\text { Experimental } \\
\text { conditions }\end{array}$ & Total hydrogen yield (L) & $\begin{array}{c}\text { Theoretical hydrogen } \\
\text { production rate }(\mathrm{L})\end{array}$ & $\begin{array}{c}\text { Hydrogen production rate } \\
(\%)\end{array}$ \\
\hline $10 \mathrm{wt} \%-65^{\circ} \mathrm{C}$ & 4.125 & 4.408 & 93.58 \\
$20 \mathrm{wt} \%-65^{\circ} \mathrm{C}$ & 4.37 & 4.408 & 99.13 \\
$30 \mathrm{wt} \%-65^{\circ} \mathrm{C}$ & 3.991 & 4.408 & 90.54 \\
$30 \mathrm{wt} \%-70^{\circ} \mathrm{C}$ & 3.655 & 4.408 & 82.92 \\
\hline
\end{tabular}

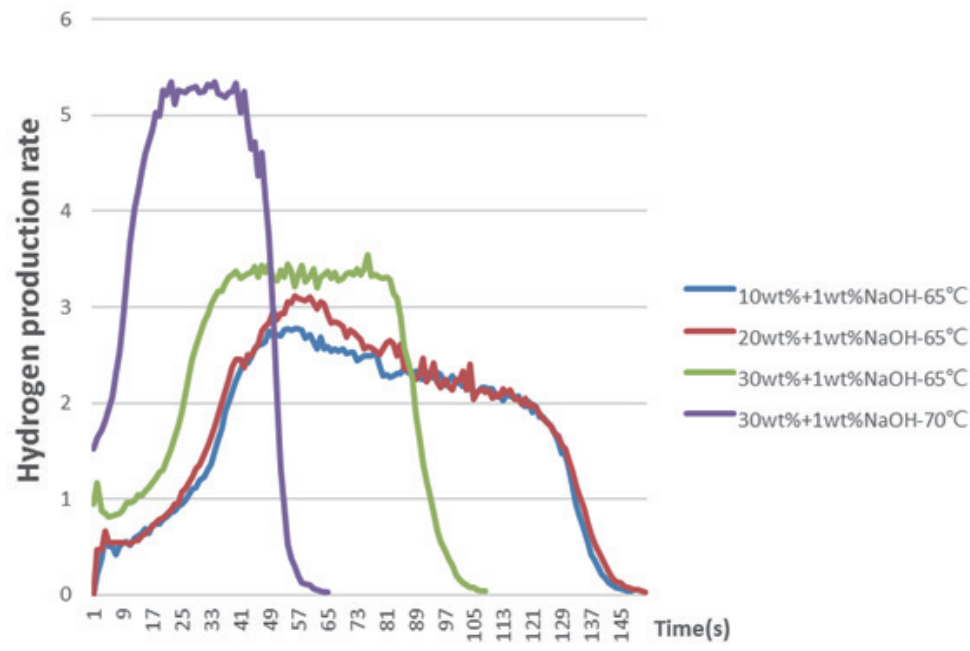

Fig. 8. (Color online) Comparison of hydrogen production rates at $\mathrm{Co} / \mathrm{Al}_{2} \mathrm{O}_{3}$ catalyst bed temperatures of 65 and $70{ }^{\circ} \mathrm{C}$.

By comparing the maximum hydrogen production efficiency and hydrogen production rate at the two catalyst bed temperatures, it was observed that the temperature rose to $70{ }^{\circ} \mathrm{C}$. However, a very drastic hydrolysis reaction gasifies the water solution, reducing the hydrogen production rate. 


\section{Discussion}

We use $\gamma-\mathrm{Al}_{2} \mathrm{O}_{3}$ to load the non-noble metal catalyst Co with three catalyst bed temperatures $\left(25,65\right.$, and $\left.70{ }^{\circ} \mathrm{C}\right)$ and three chelate concentrations $(10,20$, and $30 \mathrm{wt} \%)$ to produce a catalyst for catalyzing the hydrolytic hydrogen production reaction of $\mathrm{NaBH} 4$, and we test the hydrogen production efficiency of the $\mathrm{NaBH}_{4}$ solution at the same concentration of $10 \mathrm{wt} \% \mathrm{NaBH}_{4}+1$ wt $\% \mathrm{NaOH}$.

The results of comparing the catalyst efficiencies are summarized as follows:

(1) In comparison with the catalyst produced by Kim et al., (14) high-temperature calcination is not required, and the hydrogen production efficiency remains good after the baking temperature is reduced. Lowering the baking temperature also reduces the time and increases the convenience of production.

(2) The catalyst carrier is $\gamma-\mathrm{Al}_{2} \mathrm{O}_{3}$, and the metal catalyst soaking time is extended from 24 to $72 \mathrm{~h}$, so that the catalyst can produce more hydrogen within the same time.

(3) Hsueh et al. ${ }^{(15)}$ used $\mathrm{RuCl}_{3}$ as the raw material of the metal catalyst. The non-noble metal chloride $\mathrm{CoCl}_{2}$ used as the raw material in this study is 10 times less expensive than $\mathrm{RuCl}_{3}$, allowing more catalyst to be produced at the same cost.

(4) The hydrogen production efficiencies obtained in this study are shown in Fig. 8. It is clear that the hydrogen production efficiency of the catalyst carrier at a chelate concentration of $30 \mathrm{wt} \%$ is higher than those at other chelate concentrations, and that the $\mathrm{Co}^{2+} / \mathrm{Al}_{2} \mathrm{O}_{3}$ catalyst with a catalyst bed temperature of $70{ }^{\circ} \mathrm{C}$ has the maximum hydrogen production rate of $5300 \mathrm{ml} / \mathrm{min} \mathrm{g}$ cat.

(5) The hydrogen production efficiency of the $\mathrm{Co}^{2+} / \mathrm{Al}_{2} \mathrm{O}_{3}$ catalyst at a chelate concentration of $10 \mathrm{wt} \%$ is lower than that of the catalyst of the same catalyst carrier under different conditions. Because this batch of the catalyst has a lower chelate concentration and a shorter chelation time, $\mathrm{Co}^{2+}$ cannot adhere to the catalyst surface effectively during chelation, which may reduce the content of the metal catalyst on the catalyst carrier surface. The chelate concentration and time will be optimized in future work.

\section{Conclusion}

The non-noble metal catalyst $\mathrm{Co}$ is loaded on a $\gamma-\mathrm{Al}_{2} \mathrm{O}_{3}$ catalyst carrier, then subjected to Table 1 manufacturing to produce a catalyst for catalyzing the hydrolytic hydrogen production reaction of $\mathrm{NaBH}_{4}$. The catalyst is added in $10 \mathrm{wt} \% \mathrm{NaBH}_{4}+1 \mathrm{wt} \% \mathrm{NaOH}$ solution to generate hydrogen. According to the experimental results, the $\mathrm{Co}^{2+} / \mathrm{Al}_{2} \mathrm{O}_{3}$ catalyst with a chelate concentration of $30 \mathrm{wt} \%$ has the maximum hydrogen production rate of $5300 \mathrm{ml} / \mathrm{min} \mathrm{g}$ cat at a catalyst bed temperature of $70{ }^{\circ} \mathrm{C}$, and the $\mathrm{Co}^{2+} / \mathrm{Al}_{2} \mathrm{O}_{3}$ catalyst with a chelate concentration of $20 \mathrm{wt} \%$ has the maximum hydrogen production rate of $99.13 \%$ at a catalyst bed temperature of $65^{\circ} \mathrm{C}$. This catalyst is characterized by convenient production and a low cost, and it is expected to contribute to reducing the cost of hydrogen production from $\mathrm{NaBH}_{4}$. 


\section{Acknowledgments}

The authors acknowledge financial support from the Ministry of Science and Technology of Taiwan under grant numbers MOST 108-2221-E-167-014 and MOST 109-2221-E-167-006.

\section{References}

1 M. Mench: Fuel Cell Engines (John Wiley \& Sons Inc., USA, 2008) Chap. 2.

2 W. Chen, L. Z. Ouyang, J. W. Liu, X. D. Yao, H. Wang, Z. W. Liu, and M. Zhu: J. Power Sources 359 (2017) 400.

3 M. C. Wang, L. Z. Ouyang, J. W. Liu, H. Wang, and M. Zhu: J. Alloys Compd. 717 (2017) 48.

4 H. A. Bandal, A. R. Jadhav, and H. Kim: J. Alloys Compd. 699 (2017) 1057.

5 T. Kim: Energy 69 (2014) 721.

6 C. H. Liu, B. H. Chen, C. L. Hsueh, J. R. Ku, and F. H. Tsau: J. Power Sources 195 (2010) 3887.

7 H. I. Chlesinger, H. C. Brown, A. B. Brown, J. R. Finholt, H. R. Gilbreath, E. K. Hockstra, and J. A. Hydo: Chem. Soc. 75 (1953) 215.

8 Z. Li, H. Li, L. Wang, T. Liu, T. T. Zhang, G. Wang, and G. Xie: J. Hydrogen. Energy 39 (2014) 14935.

9 M. Kreevoy: Ventron Alembic. 15 (1979) 2.

10 Y. Kojima, K. Suzuki, K. Fukumoto, M. Sasaki, T. Yamamoto, Y. Kawai, and H. Kojima: J. Hydrog. Energy 27 (2002) 1029.

11 W. Ye, H. Zhang, D. Xu, L. Ma, and B. Yi: J. Power Sources 164 (2007) 544.

12 D. Ke, Y. Tao, Y. Li, X. Zhao, L. Zhang, J. Wang, and S. Han: J. Hydrogen Energy 40 (2015) 47308.

13 G. Guella, B. Patton, and A. Miotello: J. Phys. Chem. C. 111 (2007) 18744.

14 K. Kim, T. Kim, K. Lee, and S. Kwon: J. Power Sources 196 (2011) 9069.

15 C. Hsueh, C. Chen, J. Ku, S. Tsai, Y. Hsu, and F. Tsau: J. Power Sources 177 (2008) 485.

\section{About the Authors}

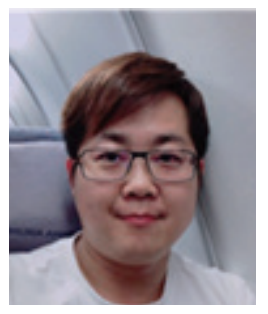

Jyun-Lin Lai received his B.S. degree from Hsiuping University, Taiwan, in 2004 and his M.S. degree from the Department of Refrigeration, AirConditioning and Energy Engineering at National Chin-Yi University of Technology, Taichung City, Taiwan, in 2008. He has been pursuing his Ph.D. studies at the same college since 2012. His research interests are in fuel cells. Since 2010, his work has focused on car headlight design.

(bd90067@gmail.com)

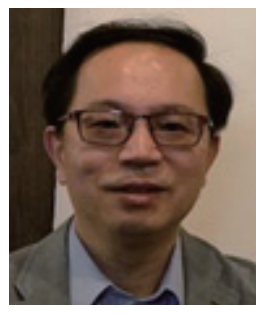

Win-Jet Luo received his master's degree in engineering in 1994 and his Ph.D. degree in engineering in 2000 from National Chen Kung University (NCKU), Taiwan. After he received his Ph.D. degree, he started teaching in the Department of Refrigeration, Air-Conditioning and Energy Engineering and in the Electrical Engineering program. He was promoted to professor in 2008. Currently, he is a professor in the Graduate Institute of Precision Manufacturing at National Chin-Yi University of Technology, Taichung City, Taiwan. His research has mainly focused on computational fluid dynamics, micro-electromechanical systems, ventilation, energy saving, fuel cells, and microsensors. He has published several research papers in prestigious international journals and has been invited to serve as a reviewer for journals. (wjluo@ncut.edu.tw) 


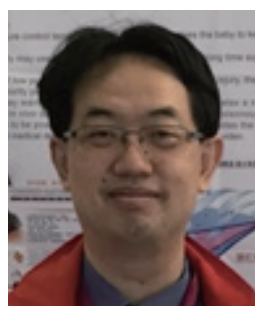

Yean-Der Kuan is a distinguished professor and former chairman (2013/022019/01) of the Department of Refrigeration, Air-Conditioning and Energy Engineering at National Chin-Yi University of Technology, Taichung City, Taiwan. He received his Ph.D. degree from the Department of Mechanical and Aerospace Engineering at the University of Missouri, USA, in 2000. Currently, he is the director of the Taiwan Society of Heating, Refrigeration and Air-Conditioning, the director of the Taiwan Energy Association, the director of the Taiwan Association for Hydrogen Energy and Fuel Cells, and a member of the American Society of Heating, Refrigerating, and AirConditioning. His research interests include the fields of engineering saving and renewable energies, and air-conditioning components and systems. (ydkuan@ncut.edu.tw) 